\title{
The Task-based Teaching of Writing to Big Classes in Chinese EFL Setting
}

\author{
Miao Hai-yan ${ }^{1}$ \\ ${ }^{1}$ School of Foreign Languages, Jiangxi Normal University, Nanchang, China \\ Correspondence: Miao Hai-yan, School of Foreign Languages, Yaohu Campus, Jiangxi Normal University, \\ 330022 Nanchang, China. Tel: 135-7691-9378. E-mail: salomehy@aliyun.com
}

Received: December 16, 2013 Accepted: January 17, 2014 Online Published: February 12, 2014

doi:10.5539/elt.v7n3p63 URL: http://dx.doi.org/10.5539/elt.v7n3p63

The research is financed by Jiangxi Province's Educational Science Program "Chunk Acquisition in Foreign Language Classrooms" (12YB091).

\begin{abstract}
This paper explores how to teach English writing to big classes in China from the task-based perspective. Based on a comparison between the traditional 3Ps approach and the tasked-based approach, the paper proposes a practical linear procedure as to how to teach English writing in the task-based classroom to big classes. An empirical study is conducted in the form of questionnaires to test the effectiveness of this task-based procedure to foreign language writing in the Chinese EFL setting. Results show that the task-based approach is effective to teach big classes English writing, as it deepens students' understanding of the task-based approach and enhances various aspects of writing. However, there are several factors calling for future attention, such as teachers' roles, monitoring and evaluation in the practice of task-based instruction. It is hoped that this proposed procedure of task-based approach can serve as an inspiration for other foreign language teachers and stimulate more studies in task-based learning and teaching.
\end{abstract}

Keywords: task-based, big classes, tasks, the teaching of writing

\section{Introduction}

\subsection{Introduce the Problem}

Chinese college students are required to learn English for the first two years in college, and they usually learn English in big classes of 40 students or even more. Under such circumstances, the teaching of writing has been a headache particularly for both college teachers and students. On the one hand, teachers exhaust themselves with teaching students what good and effective writing should be; On the other hand, students work extremely hard to do what they are told to. However, the result is usually not that satisfying.

\subsection{Explore Importance of the Problem}

It is commonplace to see, in big classes, teachers emphasize on the linguistic correctness of students' writing, thus providing students with negative evidence of correction most of the time, paying little attention to other aspects of their writing. All this makes foreign language writing difficult both to teach and to learn. Then emerges the question of how to teach foreign language writing more ease and more efficiency with willing participation from the students. In this article, we will approach the teaching of writing from the perspective of the task-based approach, with the sincere hope that it can be of value and practical help to the teaching of writing in big classes in the Chinese setting.

\section{Review of Approaches to Teaching Writing}

\subsection{The Traditional 3Ps Approach}

One of the most influential approaches in the teaching of writing in China is that of the 3Ps: presentation, practice, and production. At the first stage, teachers will present explicitly or implicitly certain grammatical rules or important sentence patterns so as to maximize the chances that these can be understood and internalized by the students. In this stage, the aim is to impart language knowledge to students, but students usually just receive this knowledge passively. Then comes the second stage, which is characterized by a series of practice activities 
designed to automatize the newly taught language knowledge. During this stage, the students are assigned some exercises to practice, the content of which they have no control over, but simply memorize the newly taught knowledge by practice and practice. Generally speaking, these practice assignments are mostly language drills and provide students ready-made meanings or no meanings at all, thus students would not be expressing personal thoughts. In fact, these exercises can be so boring and autonomous that the students may feel dull and strained. At the production stage, the students will be given more freedom, since they are required to produce language individually and more spontaneously, depending on what personal meanings or feelings they want to convey.

The popularity of the 3Ps approach can be explained by the following reasons: it can help teachers to secure their roles as teachers, and also easy to conduct in big classes. The underlying concept of this approach is the input-output hypothesis, which means that students have to receive enough input before they are able to produce something in the target language. However, the link between input and output is not as strong as it is supposed to, as Chinese students learn English as a foreign language, which means that their language input relies mostly on the teacher and the class. Besides, input does not necessarily lead to intake, which in turn does not equal output. The target of language learning thus is simply the mastery of elements of this system, but not the actual use of the language.

\subsection{The Task-Based Approach}

The concept of task-based learning and teaching is not new, for tasks have been used in foreign language classrooms since at least the mid-1970s. And the term "task" came into deliberate use in applied linguistics in the early 1980s, and nowadays it is a widely used concept both in second language syllabus design and in second language acquisition research. In order to challenge the traditional linguistically-based approach, researchers have proposed many task-based syllabuses, for example, Prabhu's (1987) Procedural syllabus, Breen's (1984) Process syllabus and Long's (1985) Task syllabus. Since then, task-based learning and teaching has become extremely popular among teachers and it is integrated into the communicative language teaching for its promotion of naturalistic learning and stimulation of acquisitional processes.

Task-based learning and teaching is an overall approach, as it advocates that all the language skills should be integrated in the process of learning and teaching. According to Nunan (2004), tasked-based teaching should put the emphasis on learning to communicate through interaction in the target language, authentic texts should be introduced into the learning, focus on form should be advocated, but learners' own personal experiences are also important to classroom learning; it should link classroom language learning with language activation outside the classroom.

There are many definitions of task. Nunan (1989) defines task as "a piece of classroom work which involves learners in comprehending, manipulating, producing or interacting in the target language". Skehan's (1998) definition goes like this, "a task is an activity in which meaning is primary". Ellis (2003) defines a task as a workplan that requires learners to process language pragmatically. No matter how many definitions there are, the common thread running through them is the focus on the authentic use of language for meaningful communicative purposes beyond the language classroom. Thus, students learn by doing tasks.

Tasks can be categorized into different types. Based on the relationship between tasks and classroom teaching, there are real-world tasks and classroom learning tasks; while according to the characteristics and the purposes of interaction, we will have five types of tasks, namely, the jig-saw task, the problem-solving task, the decision-making task, the opinion-exchanging task and the information-gap task (Rubdy, 1998). However different the tasks seem to be, they all stress the importance of activity and the process of meaning negotiation to promote learning by doing.

\subsection{Implications for Teaching Writing in Big Classes in China}

It seems that teachers should reconsider their adoption of the linguistically-based approach and the 3Ps model, since it neither achieves what it aspires to, nor does it motivate students' interest in writing. As tasks can help students to engage in activities and concentrate more on content, teachers may be recommended to apply task-based instruction in their teaching of writing. In other words, teachers are encouraged to teach writing by doing a series of well-designed tasks. In fact, task engagement is said to be a turning point in foreign language development. As for teachers, there are four aspects they have to pay extreme attention to in the process of teaching writing, that is, prudent needs analysis of students, careful selection of authentic teaching materials, attempts to engage students in meaningful communicative activities.

In order to teach writing, teachers should first of all do a needs-analysis, so that they can get an idea of how students will need to use the language in real life. In fact, analysis of students' needs will help teachers to set the 
teaching goals, decide the teaching materials and arrange the activities to be carried out in class. The authenticity of teaching materials is very important in a foreign language classroom for many reasons. Authentic materials can enliven the classroom, introduce life into the classroom, help to motivate students to meaningful learning through enjoyment, provide students more contact with the real-life language, and increase the cultural background elements. For teachers teaching writing for college students, they may choose materials from newspapers, interviews, public announcements, cartoon strips, textbooks, media extracts and novels. The next thing concerns with how to get the students engaged in the meaningful activities. In task-based classrooms, we emphasize communicative activities that require students to exchange personal information, to solve problems or to make a collective judgment. All this requires the students to actively engage in the tasks, and to successfully complete the tasks. Actually, the students may be encouraged to participate in pair work, group discussion or teacher-student interaction, all belonging to dialogic encounters.

For its importance in language teaching, the task-based approach has aroused great interest from Chinese scholars as well. Wu (2010) studies the influence of tasks on vocabulary acquisition. Pan (2007) explores task design in listening comprehension tests. In this paper, we aim to study how to teach writing to big classes from the task-based perspective in the Chinese setting. As we know, college students are adults and they must be mature in thinking. It follows that in the teaching of writing, teachers should not focus on only the forms of the language but also the meaningfulness of the activities in classroom through which thinking emerges.

Bakhtin (c.f. Platt \& Brooks, 2002) argues that "Truth is not born nor is it to be found inside the head of an individual person, it is born between people collectively searching for truth, in the process of their dialogic interaction. Volosinov (c.f. Platt \& Brooks, 2002) further claims, "language acquires life and historically evolves precisely here, in concrete verbal communication."

\section{Task-Based Sample Lesson Plan}

The following lesson plan aims to demonstrate how teachers can teach students English writing more efficiently in the task-based big classes.

There are three stages in implementing the task-based instruction, namely, pre-task activities, during-task activities and post-task activities. It is worth pointing out that time allotment is also very important, as it can press students forward. The time available for this class is two hours, and the students are required to write their after-thoughts on "Turning off TV: a Quiet Hour", Unit 4, College English I.

Aim: To write a short article about 150 words in English

Topic: No set topic, but write on their after-thoughts

Time: Two hours

Stage 1: Pre-task activities (20 minutes)

Pre-task activities have two purposes. One is to teach, mobilize or make prominent the language that relates to the task itself, for example, the useful vocabulary or important functionality sentence patterns. Another is to provide students with some background knowledge so as to help them recall schematic knowledge when completing the task. The teacher may hand out materials on related topics, such as "leisure time after work", "means of entertainment", "family activities after supper", to reduce the cognitive load on the part of the students.

Stage 2: During-task activities (80 minutes)

1) Pair Work (15 minutes)

At this stage, the students are encouraged to engage as much as possible in the tasks and to complete them. The teacher may write some questions on the blackboard for the students to discuss, for example:

What impresses you most in this article?

Do you think it necessary to turn off TV for a quiet hour in America?

What if this happens in China? And your predictions?

Then the teacher can divide the students into pairs to discuss these questions. Meanwhile, the teacher should not intervene in the students' discussion so as to allow natural language acquisitional processes to operate; but whenever the students need help, the teacher should stand out. After this preliminary discussion, the students may be asked to report the results of their pair work.

2) Group Discussion (15 minutes) 
Compared with pair work, the advantage of group discussion is self-evident: every participant has his share of information to contribute to the communication process, and therefore more participants will make the communication more lively and more meaningful. At the same time, the teacher should monitor the whole process and offer help if possible. The students may be divided into small groups of more than three people to rediscuss the above questions and to determine what they will write. Upon deciding the topic to write about, the students may embark on their writing.

\section{3) First Draft (30 minutes)}

Students can think over what they have discussed up till now, and plunge directly into writing. At this moment, the students should not worry about grammatical mistakes, and all they should do is to put down their ideas. At this stage, the teacher should withdraw so as not to prevent the natural flow of the students' ideas and their expressiveness. This is also done to elicit personal opinions from students so as to get them more involved in the completion of the task. As for this kind of writing, students' task is to put the information onto paper in a logical manner, not worrying about grammar, spelling or handwriting.

4) Discussion of the Product (20 minutes)

After the completion of the first draft, the students are divided into small groups, and a group leader is nominated. Students are required to exchange their first drafts of writing and criticisms concerning vocabulary, grammar, punctuation, structure and logic are welcome. It is then the group leader's duty to report the results of the group discussion.

Stage 3: Post-task activities (20 minutes)

Before this stage, the emphasis is on the meaningfulness and fluency of the communication process, and the expressiveness of ideas. However, this alone cannot guarantee good writing in itself, as we also need accuracy and refined language to call our writing good. Therefore at this stage, the teacher should direct the students' attention to the accuracy of language and the way of restructuring their sentences so as to better their writing. Based on the group leader's report, the teacher may get a brief idea of the students' weaknesses and strengths. In order to present in a more clear way, the teacher can write down the language points, chunks or functionality patterns on the blackboard. To make sure that the students have grasped all that is being taught, the teacher may offer the students some exercises in order to check on the students.

\section{Empirical Study}

The empirical study tests the effectiveness of the task-based approach to teaching writing to big classes. The above sample lesson plan well illustrates how task-based approach to teaching writing is applied in big classes. The study is supposed to validate whether task-based approach is feasible in big classes for teaching writing in the Chinese setting.

\subsection{Subject Characteristics}

Four intact natural classes of the author are randomly selected as subjects. All the subjects are first-year Chinese college students, and their mother tongue is Chinese. Besides, their experience with English is similar, that is, they all have spent 10 years of learning English since primary school.

\subsection{Sampling Procedures}

\subsubsection{Sample Size, Power, and Precision}

For each class of the subjects, there are 50-70 students, with altogether 196 students. All the 196 subjects were asked to finish the questionnaire in class. They were also notified that this questionnaire aims to know about their beliefs and experiences of the writing classes, thus the it has nothing to do with their test grades and evaluations. When time is up, all the questionnaires are collected, checked and counted. Altogether there are 176 valid copies.

\subsubsection{Measures and Covariates}

The survey mainly takes place in the form of questionnaires (see Appendix), which includes 2 categories: multiple choice and rating. Questions 1 to 6 are designed to test related theoretical knowledge about writing and the task-based approach. Question 7 aims to find out the effectiveness of the task-based approach. Question 8 is rating, designed to reveal what aspects of writing abilities have been enhanced through the task-based approach. In order to make the questionnaire more understandable, it is written in Chinese. After one semester of conducting the task-based approach to writing, the students were asked to do the questionnaire. 


\subsubsection{Experimental Manipulations or Interventions}

The survey is carried out at the end of the task-based instruction session. Questionnaires are designed, printed and then handed out to the student participants. Each participant gets a copy and is required to finish the questionnaire with careful thought within 15 minutes.

\subsection{Data Analysis}

\subsubsection{Question 1-6}

The data from question 1-6 show that the students overall command of theoretical knowledge concerning writing and the task-based approach is for the most part quite satisfying, but the students' understanding of teachers' roles in task-based writing classes fall short of expectations. Table 1 demonstrates the percentage of correctness of the right answer to questions 1 to 6 in the survey. According to table 1,95.54\% of the students think writing should not only be meaning-based; $89.63 \%$ of the students treat English writing mostly as meaning-based and syntactically-structured; $80.68 \%$ of the students hold the view that task-based writing should be meaning-based and with a focus on form; $75.14 \%$ of the students think tasks serve as means to accomplish writing; $53.44 \%$ of the students don't think teachers provide constant and enough help; $96.64 \%$ of the students admit that they should work more interactively.

Table 1. Percentage of Correctness for Questions 1-6

\begin{tabular}{lll}
\hline \multicolumn{2}{l}{ Questions } & Percentage of correctness \\
\hline Q1 & Writing & $95.54 \%$ \\
Q2 & English writing & $89.63 \%$ \\
Q3 & Task-based writing & $80.68 \%$ \\
Q4 & Tasks & $75.14 \%$ \\
Q5 & Role of teachers & $53.44 \%$ \\
Q6 & Role of students & $96.64 \%$ \\
\hline
\end{tabular}

\subsubsection{Question 7}

Figure 1 presents the percentage of students as to their evaluation of whether the task-based approach is a success in improving their English writing. There is an average of $67.98 \%$ of the surveyed students considering the task-based approach to writing has helped to improve their writing. About $20.79 \%$ think the approach has not affected their writing so much. Only $11.23 \%$ of them take this approach as not being able to improve their writing at all. This result indicates that the majority of the students approve of this task-based approach to writing.

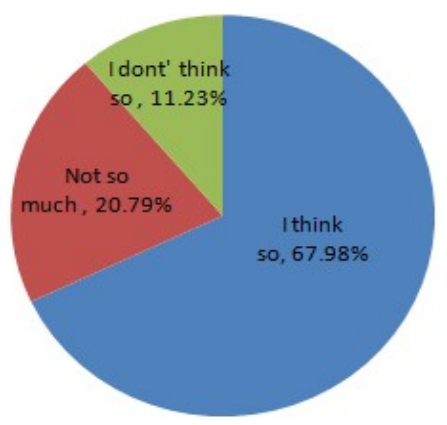

Figure 1. Percentage of students in favor of the task-based approach

\subsubsection{Question 8}

Table 2 shows the mean scores on the aspects of writing that students think they have made progress on through the task-based approach. As can be seen from Table 2, from the students' perspective, the task-based approach to writing in general has been quite satisfactory. These aspects include the role of the task-based approach in aiding writing, building up confidence or interest, helping to express meaning, focusing on language form, fostering 
autonomous learning, providing feedback, enhancing cooperation and strengthening the awareness of syntactic patterns. However, there are two aspects in English writing, namely monitoring (average score 2.7) and evaluation (average score 3.0), which fall short of students' expectations.

Table 2. Mean scores on aspects of writing improved

\begin{tabular}{llllll}
\hline & Aid to writing & Confidence/Interest & Meaning & Language form & Autonomous learning \\
\hline Score & 4.5 & 4 & 4.4 & 4.6 & 4 \\
\hline & Feedback & Monitoring writing & Evaluation & Cooperation & Syntactic patterns \\
\hline Score & 4.4 & 2.7 & 3.0 & 4 & 4.3 \\
\hline
\end{tabular}

(1=very bad; $2=$ bad; $3=$ so-so; $4=$ good; $5=$ very good $)$

\section{Discussion}

The task-based approach to writing has proved to be quite a success, having benefited both teacher and students. On the one hand, it reduces the stress and load on the teacher for teaching big classes. On the other hand, students find more opportunities to clarify meaning through interaction and the negotiation of meaning. Since the introduction of the task-based approach into the classroom, students are more willing to cooperate with their classmates and teacher in order to write better English essays. The task-based approach to writing has been popular with the majority of the students in the author's English classes, but there are some factors that need further attention.

The study results show that theoretically the students are aware of the importance of task-based teaching and learning behind their English learning as a foreign language, and they know quite well their expected roles but unfortunately not their teacher's role. Practically, the students approve of the effectiveness of the task-based approach. The task-based approach brings great benefits to the English writing process, but not monitoring and evaluation. These phenomena may be attributed to the following three possible reasons.

First, writing abilities have been emphasized throughout the Chinese education, which may exert an influence on students' perception of English writing. Chinese students, during the first early years in primary school, are required to write compositions. In formal schooling, Chinese students are usually taught such tenets of writing as “Empty words do not travel afar" (in Chinese “言之无物, 行而不远”), and “Correction and polish makes good writing” (in Chinese “疪病不必待人指摘, 多作自能见之”), which coincide with those in the task-based approach to writing, thus the students' perception of Chinese writing may have been transferred to English writing.

Second, the traditional Chinese attitude towards teaching and teachers affect students' understanding of teachers' roles. Confucianism is deeply rooted in the Chinese culture, and according to which, one must respect and listen to his seniors. It is common practice that Chinese students are expected to listen to the teacher, since the teacher is supposed to be the authority who imparts knowledge and solves students' puzzles. Therefore, Chinese students, more used to the traditional 3Ps where students do as told to, rely on their teachers to play a principal role in their classroom learning.

Last but not least, the significance of engagement in tasks is crucial. Engagement in meaningful activities in classrooms is such a crucial step that it may directly influence the effect and quality of teaching. All this can be attested by the effectiveness of our task-based approach to teaching English writing in big classes. According to Vygotsky (1978), social interaction plays a fundamental role in the development of cognition. Learning arises from interactions with others rather than in isolation. In our case, different tasks used in classroom offer a great opportunity for students to interact with their fellow classmates.

\section{Conclusions}

Recent studies have confirmed that the 3Ps approach is extremely effective for teaching simple language at lower levels (Gass \& Selinker, 2008). However, it is often frustrating and inefficient to apply this approach to teaching college students, especially in the big writing class, because they are adult learners who, after nearly 10 years studying English since primary school, have already grasped the basics of English.

On the other hand, the task-based approach can prove to be very successful, for it can fit neatly into the classroom description. In the task-based classroom, the emphasis is on the task, where importance is attached 
both to language use through language activation and language study. What is worth mentioning is that in the task-based language classroom, the tasks and their sequences are not fixed so that the teacher can weigh what is more important to the students. Thus the role of the teacher is not confined to a didactic instructor, but also a counselor, facilitator, partner and negotiator, who should help the students not with what they are writing but how they can achieve the final success, that is, the actual writing. As for the sample plan, it has turned out to be very effective, and may be tried out for other types of learning and teaching; yet it must be pointed out that it should be used flexibly in order to cater to the needs of different types of learners.

\section{References}

Breen, M. (1984). Process in syllabus design. In C. J. Brumfit (Ed.), General English syllabus design—ELT documents (pp. 47-60). Oxford: Pergamon.

Gass, S., \& Selinker, L. (2008). Second language acquisition: An introductory course. Routledge: Tailor \& Francis Group.

Long, M. H. (1985). A role for instruction in second language acquisition: Tasked-based language teaching. In K. Hyltenstam, \& M. Pieneman (Eds.), Modelling and assessing second language acquisition (pp. 77-100). Clevedon: Multilingual Matters.

Nunan, D. (2004). Task-based language teaching. Cambridge: Cambridge University Press.

Nunan, D. (1989). Designing tasks for the communicative classroom. Cambridge: Cambridge University Press.

Prabhu, N. S. (1987). Second language pedagogy. Oxford: Oxford University Press.

Pan, Z. X. (2007). Study on listening task design in communicative language testing. Foreign Language World, 1, 84-96.

Richards, J., \& Rogers, T. (2002). Approaches and methods in language teaching. Cambridge: Cambridge University Press.

Rubdy, R. (1998). Key concepts in ELT task. ELT Journal, 52(3), 264-265. http://dx.doi.org/10.1093/elt/52.3.264

Skehan, P. (1998). A cognitive approach to language learning. Oxford: Oxford University Press.

Vygotsky, L. S. (1978). Mind in society. Cambridge, Mass.: Harvard University Press.

Wu, X. D. (2010). Can learning tasks affect incidental vocabulary acquisition? Involvement Load Hypothesis revisited. Foreign Language Teaching and Research, 42(2), 109-115.

\section{Appendix}

1) Writing is to ( ).

A. Put the memorized knowledge into production

B. To express one's thoughts

C. Construct correct sentences

2) For you at the current stage of English learning, English writing should be such a case that ( ).

A. Students put the memorized English words and sentence patterns into use

B. Students use English words and sentence patterns to express meaning

C. Students test whether English words and sentence patterns are acquired

3) The task-based writing should be such a case that ( ).

A. Students express their feelings and thoughts in English

B. Students practice their knowledge of English, with a focus on form

C. Students express themselves in English, with a focus on form

4) In task-based teaching, tasks should be ( ).

A. A means to accomplish the writing process

B. A process to communicate with others

C. A good method of learning new knowledge

5) Teachers in task-based teaching should ( ).

A. Provide students with guidance and supervision in the process of doing tasks 
B. Give way to tasks

C. Impart knowledge to students more conveniently with the help of tasks

6) Students in task-based learning should ( ).

A. The principal part

B. Subordinate to teachers

C. Subordinate to other classmates while doing tasks

7) Generally speaking, do you think this task-based approach help you better improve in your English writing? ( )
A. I think so
B. Not so much
C. I don't think so

8) The following are the description of possible aspects of writing that may be enhanced through task-based teaching. What aspects do you think are useful to your English writing? Please match them with equivalent numerical figures. ( $1=$ very bad; $2=$ bad; $3=$ so-so; $4=$ good; $5=$ very good)

A. Providing facilitation and aid for the English writing process ( )

B. Motivating and helping students gain interest and confidence in English writing ( )

C. Organizing on-line discussion, group work and other in-class and out-class English learning activities to detect and solve problems in expressing meanings or personal thoughts ( )

D. Offering guidance in terms of language form ( )

E. Training learning skills and the ability to learn autonomously with the support of web ( )

F. Detecting and diagnosing weaknesses in students' learning and writing with feedbacks ( )

G. Macro-managing and monitoring English writing ( )

H. Evaluating the writing performance and progress ( )

I. Cooperating with fellow students ( )

J. Providing consultancy on syntactic patterns or structures ( )

\section{Copyrights}

Copyright for this article is retained by the author(s), with first publication rights granted to the journal.

This is an open-access article distributed under the terms and conditions of the Creative Commons Attribution license (http://creativecommons.org/licenses/by/3.0/). 